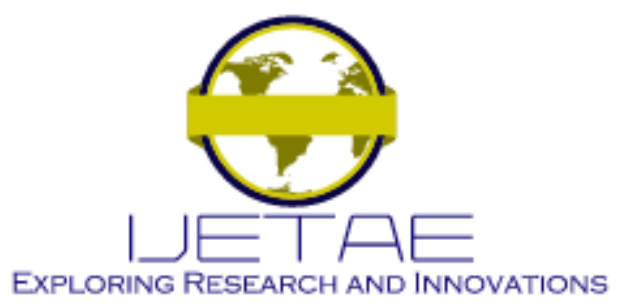

International Journal of Emerging Technology and Advanced Engineering

Website: www.ijetae.com (E-ISSN 2250-2459, Scopus Indexed, ISO 9001:2008 Certified Journal, Volume 11, Issue 12, December 2021)

\title{
Proposal for the Design of a Prototype of a Mobile Application for Sexual Health Counselling and Care for Adolescents in Northern Peru
}

\author{
Rosa Perez-Siguas ${ }^{1}$, Hernan Matta-Solis ${ }^{2}$, Eduardo Matta-Solis ${ }^{3}$ \\ ${ }^{1,2,3}$ Universidad María Auxiliadora \& Av. Canto Bello 431, San Juan de Lurigancho
}

\begin{abstract}
This research article presents a proposal for prototyping a mobile application for adolescents, helping them to know more about their sexual health. This application aims to disseminate knowledge and particular attention to these adolescents that these issues should not be a matter of shame but rather something that will help them to be able to cope in today's society. That is why this application is presented in a dynamic way with interactive games, multimedia experiences and attention through a chat. The idea arose from a problem that was in northern Lima, Peru. Many adolescents have little knowledge of these issues and are exposed to sexually transmitted diseases or early pregnancies, and as a result, they stop studying or worse, die. The development of this project was carried out using an Agile Methodology called Scrum, since we had ideas or requirements of the functionalities that the application required in a short term delivering an already functional design. That's why Balsamiq Mockups was used to visualize how the design would look like by sprint of the stories that were held together. Therefore, in order to consolidate this research, a survey was launched among adolescents in Lima, Peru, showing the results we expect for this research.
\end{abstract}

Keywords - Sexual Health, Agile Methodology, Scrum, teenagers, mobile application, sexually transmitted diseases, early pregnancies.

\section{INTRODUCTION}

In the society in which we live, the word sexuality is very common, but in spite of this, there are still fears, taboos, little knowledge and discrimination [1]. The World Health Organization has mentioned that adolescents are a healthy group, but at present there is an increase in problems related to sexual health, adolescents who die in childbirth or from sexually transmitted diseases [2]. A campaign in Peru called "Inform yourself without avocados" mentions that one of the main and important causes of adolescent pregnancy is the lack of access to sexual education and information.
In Peru, there are educational centers that provide sexual health information, but they are basic and many of the adolescents are embarrassed to ask questions. In short, the level of knowledge in the homes is very questionable since parents do not have the tools to engage in conversation [3].

That is why from the point of view of this research several methodologies were examined, among them those that stood out were the Methodology development in cascade, Methodology XP and the methodology agile Scrum. The methodology of development in cascade is based on following a linear sequence, allowing to be able to visualize or to identify in fulfillment in order of each one of them. However, unlike other methodologies is that it has little integration into their processes, little coordination of their tools causing failures in the software in the process of redesign [4]. The XP methodology is an agile methodology that is only based on projects that have changing and imprecise requirements [5]. In contrast, the Scrum methodology that we will use in this research is more flexible because it helps to obtain a wealth of information when designing or developing a program, this allows the evaluation to be constant and each time that ideas are presented only make a feedback to that process and adjust it to the need of the user allowing the risk of failure [4]. In addition, Scrum is based on the empirical in what is known helping to have a more accurate approach to software [6].

In our application we will take into account the user's needs that is why we collect a lot of information of what they would expect to be a teaching of sexual education, thanks to that we make use of technology to make our design and that is why in our research we will use the software Balsamiq mockups. The user will be able to navigate within the application through various sections, starting with a personal survey to evaluate the degree of knowledge that is at the beginning, then you can enter games of questions, some of the questions taken from a research [7]. 


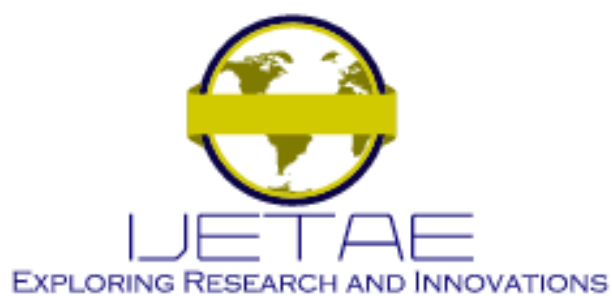

International Journal of Emerging Technology and Advanced Engineering

Website: www.ijetae.com (E-ISSN 2250-2459, Scopus Indexed, ISO 9001:2008 Certified Journal, Volume 11, Issue 12, December 2021)

These phases are level by level, from the most basic to the most difficult. But in order to help them, they will have to accumulate scores that will be useful for the final phases where help will be required to approach the answer. In addition, the adolescents will be able to navigate in a multimedia section where they will always see dynamic and easy to understand videos to reinforce the knowledge they will have about their sexual health. And finally, they will have access to an online conversation based on a Chat Bot system where they can ask any questions that may arise and get answers immediately.

Our objective is to be able to propose a mobile application for the orientation and attention in sexual health to the adolescents of Lima. Giving them all the knowledge that we didn't see before and that we have now. Helping them to know more about themselves and to take care of sexually transmitted diseases.

In this way, our present research will be structured in the following way, in Section II the methodology will be made. Therefore, Section III will show the case study. In addition, Section IV will elaborate on the results and discussions. Finally, in Section V the conclusions.

\section{Methodology}

In this section we will detail the steps to follow for the design proposal of the mobile application prototype, so we will use the Scrum Methodology and technological tools such as Balsamiq for the design of the prototype. In addition to Google Forms to conduct a survey that we will use to demonstrate the lack of knowledge of many adolescents regarding their sexual health and how useful this proposal would be for them.

\section{A. Scrum Methodology}

Scrum is an agile methodology, by which it allows a quick delivery of a software project. In other words, Scrum is a lifesaver for some organizations that have difficulties using methodologies for the development of their software, Scrum does it in a simple way and delivers on time [8]. Unlike other Scrum methodologies, it makes the user or client part of the work team. It is also possible that some requirements may change, but thanks to this methodology you do not have to start from scratch [9]. It should be said that Scrum focuses on short iterations that deliver a part of the product. Also, it is an iterative and incremental method that specifies the practices and values on the other disciplines [10]. Scrum is structured in work cycles known as Sprints.
They last from 1 to 4 weeks, the Scrum Team at the beginning of the Sprint selects the user stories from a prioritized list, commits to finish the sprint and at the end the Scrum Team reviews those interested in the project and shows the built product [11]. The process or phases of the Scrum methodology is shown in the research [12].

Project Preparation: Known as Sprint 0, the business case is well known, whose objective is to be able to make decisions that add value to the final product. In this phase, tasks such as defining the initial backlog, deliverables and estimating the backlog are developed.

Sprint Planning: team with the intention of selecting the backlog the functionalities to be worked on. In addition, the estimation by Sprint is developed.

Development of Sprint: In this phase where the execution of the product is, it will develop 3 meetings of which are Planning Meeting, Daily Meeting, Sprint Review Meeting and Retrospective Meeting [13].

\section{B. Tools for the elaboration of the prototype}

Balsamiq Mockups is a mockup tool that allows us to quickly and easily develop the web or mobile environment of the application user view [14]. It is a powerful tool for the elaboration of sketches for the development of the application, it is easy to use. Google Forms is a tool of Google Suite useful for the elaboration of surveys, but virtually, which has revolutionized the old forms of data collection [15].

\section{Mobile Application Structure}

The proposed application will have an Android operating system, created by Google. This system is open source based on Linux, is very effective for applications because it is compatible with different devices [16]. In addition, our programming code will be based on JavaScript, a language born to replace HTML as the standard for web page programming. The goal is to achieve a hybrid application, where the information and the way to present it are clearly separated, this will help us to have order and quality in our code in a simple way [17]. Therefore, for our information storage we will use SQL Server, a database manager that has a wide adaptability for information management in mobile applications and service-oriented frameworks with a new architecture for storing visual data. The storage, navigation and efficient search of image collections make it an important tool in computing [18]. 


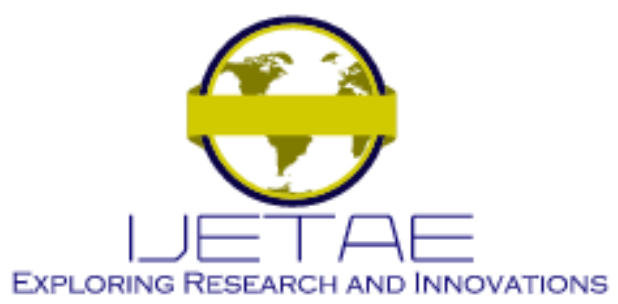

International Journal of Emerging Technology and Advanced Engineering

Website: www.ijetae.com (E-ISSN 2250-2459, Scopus Indexed, ISO 9001:2008 Certified Journal, Volume 11, Issue 12, December 2021)

Finally, to be closer to the user we will use the Chat Bot, software that interacts with users using natural language as if you were normally conversing with a person. The main objective is to simulate a human conversation, this software integrates a language architecture and computer algorithms to have an informal communication between user and computer [19].

\section{CASE OF STUDY}

This session will develop the design proposal for this research, which is why a series of steps related to the methodology session were carried out previously. The design is proposed in a dynamic way, since the target audience is young adolescents in order to provide them with orientation and attention in their sexual health in a particular way.

\section{A. Scrum Procedure}

In this first point we will detail the process of the Scrum Methodology according to the elaboration of our prototype design. To do this we had a series of ideas starting with the analysis in general of what should have and therefore the order starting from the modules, user stories and to prioritize, the assembly of the product backlog.

Preparation of the Project: We analysed the modules that can have the mobile application as: Login, User, Main Menu, Survey, Sexual Information, Testimonials and a Chatbot for communication with the user. The user stories are a list of functional or non-functional requirements that our prototype design will have depending on the epics or models that you have. There can be more than one user story within an epic or module. It begins with these three words in its nomenclature: as, I want and for, as shown in Table 1 related to its respective epic or module.

TABLE I

USER STORIES RELATED TO THE EPIC OR MODULE

\begin{tabular}{|c|c|c|}
\hline ID & User Stories & Epics or Modules \\
\hline 1 & As a teenager I want to visualize the Login to be able to enter the application. & LOGIN \\
\hline 2 & As a teenager I want to register my personal data to be able to log in. & USER \\
\hline 3 & As a teenager I want to see the main menu so I know what the application contains. & MAIN MENU \\
\hline 4 & As a teenager I want to select by buttons in the main menu to be able to enter. & MAIN MENU \\
\hline 5 & As a teenager I want to select by buttons to be able to solve the personal survey. & PERSONAL SURVEY \\
\hline 6 & $\begin{array}{l}\text { As a teenager I want to visualize the results of the survey in order to know my level of } \\
\text { knowledge. }\end{array}$ & PERSONAL SURVEY \\
\hline 7 & $\begin{array}{l}\text { As a teenager I want to visualize the question game in phases so I can choose what to } \\
\text { start with. }\end{array}$ & SEXUAL INFORMATION \\
\hline 8 & As a teenager I want to select an extra button so I can know what the right answer is. & SEXUAL INFORMATION \\
\hline 9 & As a teenager I want to visualize my score so I can know how many jokers I get. & SEXUAL INFORMATION \\
\hline 10 & As a teenager I want to select the videos by topic in order to view the content & TESTIMONIAL \\
\hline 11 & As a teenager I want to visualize the Login to be able to enter the application. & CHATBOT \\
\hline
\end{tabular}




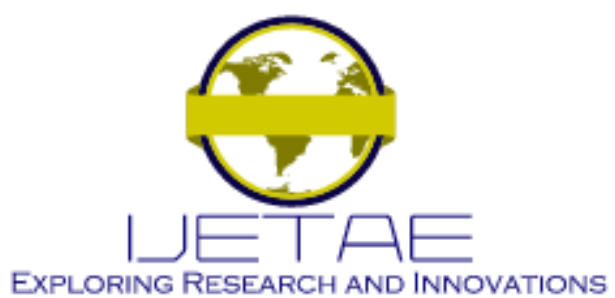

International Journal of Emerging Technology and Advanced Engineering

Website: www.ijetae.com (E-ISSN 2250-2459, Scopus Indexed, ISO 9001:2008 Certified Journal, Volume 11, Issue 12, December 2021)

In this part will be carried out the creation of the product backlog, which is the list of requirements that will have the proposal of the application of this research and that is why we had a meeting as the scrum team and made a first estimate with the user to give priority to some user stories as shown in Table 1 and to do this we began to take each story and measured based on the value and user need in an orderly manner through the so-called product stack as shown in Table 2 of the following research.

TABLE II

\section{PRODUCT BACKLOG OF OUR PROTOTYPE}

\begin{tabular}{|l|c|}
\hline User Stories & Priority \\
\hline $\begin{array}{l}\text { As a teenager I want to visualize the Login to be } \\
\text { able to enter the application. }\end{array}$ & 2 \\
\hline $\begin{array}{l}\text { As a teenager I want to register my personal data } \\
\text { to be able to log in. }\end{array}$ & 3 \\
\hline $\begin{array}{l}\text { As a teenager I want to see the main menu so I } \\
\text { know what the application contains. }\end{array}$ & 4 \\
\hline $\begin{array}{l}\text { As a teenager I want to select by buttons in the } \\
\text { main menu to be able to log in. }\end{array}$ & 5 \\
\hline $\begin{array}{l}\text { As a teenager I want to select by buttons to be able } \\
\text { to solve the personal survey. }\end{array}$ & 6 \\
\hline $\begin{array}{l}\text { As a teenager I want to see the results of the } \\
\text { survey so I can know my level of knowledge. }\end{array}$ & 6 \\
\hline $\begin{array}{l}\text { As a teenager I want to visualize the question } \\
\text { game in phases so that I can choose what to start } \\
\text { with. }\end{array}$ & 7 \\
\hline $\begin{array}{l}\text { As a teenager I want to select an extra button so I } \\
\text { can know which answer is correct. } \\
\text { ask my questions. }\end{array}$ & 6 \\
\hline $\begin{array}{l}\text { As a teenager I want to visualize my obtained } \\
\text { to be able to visualize the content. }\end{array}$ & 2 \\
\hline
\end{tabular}

\section{B. Sprint Planning}

In this part we will evaluate each user history of our backlog created previously. To do this we have used the technique known as Delphi that will be responsible for publicizing with greater security as this project evolved according to give a score to each story through a number of rounds that the product owner made the development team known as scrum team and thus know how much effort it would take us to run the design of the prototype of each user story as shown in Table $3,4,5,6,7,8,9,10,11,12$ and 13.

TABLE III

ESTIMATION OF THE FIRST STORY

\begin{tabular}{|l|c|c|c|}
\hline Round 1 & & XX & \\
\hline Round 2 & $\mathrm{X}$ & $\mathrm{X}$ & \\
\hline & 0 & 50 & 100 \\
\hline
\end{tabular}

TABLE IV

ESTIMATION OF SECOND STORY

\begin{tabular}{|l|c|c|c|}
\hline Round 1 & X & XX & \\
\hline Round 2 & & X & \\
\hline & 0 & 50 & 100 \\
\hline
\end{tabular}

TABLE V

ESTIMATION OF THE THIRD STORY

\begin{tabular}{|l|c|c|c|}
\hline Round 1 & & & XX \\
\hline Round 2 & & X & X \\
\hline & 0 & 50 & 100 \\
\hline
\end{tabular}

TABLE VI

ESTIMATION OF THE FORTH STORY

\begin{tabular}{|l|c|c|c|}
\hline Round 1 & & & XX \\
\hline Round 2 & & & XX \\
\hline & 0 & 50 & 100 \\
\hline
\end{tabular}




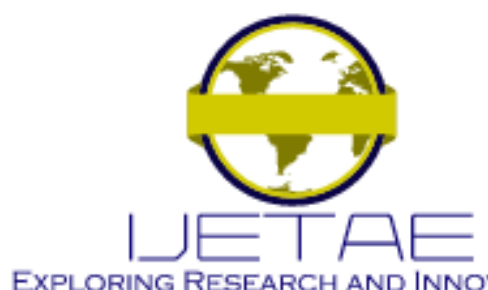

EXPLORING RESEARCH AND INNOVATIONS

International Journal of Emerging Technology and Advanced Engineering

Website: www.ijetae.com (E-ISSN 2250-2459, Scopus Indexed, ISO 9001:2008 Certified Journal, Volume 11, Issue 12, December 2021)

TABLE VII

ESTIMATION OF THE FIFTH STORY

\begin{tabular}{|l|c|c|c|}
\hline Round 1 & & X & XX \\
\hline Round 2 & & & XX \\
\hline & 0 & 50 & 100 \\
\hline
\end{tabular}

TABLE VIII

ESTIMATION OF THE SIXTH STORY

\begin{tabular}{|l|c|c|c|}
\hline Round 1 & & X & \\
\hline Round 2 & & XX & \\
\hline & 0 & 50 & 100 \\
\hline
\end{tabular}

TABLE IX

ESTIMATION OF THE SEVENTH STORY

\begin{tabular}{|l|c|c|c|}
\hline Round 1 & & X & \\
\hline Round 2 & $\mathrm{X}$ & $\mathrm{XX}$ & \\
\hline & 0 & 50 & 100 \\
\hline
\end{tabular}

TABLE X

ESTIMATION OF THE EIGHTH STORY

\begin{tabular}{|l|c|c|c|}
\hline Round 1 & & XX & \\
\hline Round 2 & & X & X \\
\hline & 0 & 50 & 100 \\
\hline
\end{tabular}

TABLE XI

ESTIMATION OF THE NINTH STORY

\begin{tabular}{|l|c|c|c|}
\hline Round 1 & & & $\mathrm{XX}$ \\
\hline Round 2 & & $\mathrm{X}$ & $\mathrm{X}$ \\
\hline & 0 & 50 & 100 \\
\hline
\end{tabular}

TABLE XII

ESTIMATION OF THE NINTH STORY

\begin{tabular}{|l|c|c|c|}
\hline Round 1 & X & X & \\
\hline Round 2 & XX & & \\
\hline & 0 & 50 & 100 \\
\hline
\end{tabular}

TABLE XIII

ESTIMATION OF THE ELEVENTH STORY

\begin{tabular}{|l|c|c|c|}
\hline Round 1 & & $\mathrm{X}$ & $\mathrm{X}$ \\
\hline Round 2 & & $\mathrm{XX}$ & \\
\hline & 0 & 50 & 100 \\
\hline
\end{tabular}

\section{Delevelopment of Sprint}

The purpose of this meeting is to select the product backlog the functionalities on which they will be executed and that will give a value to the prototype design, separating them by deliverables or sprint as shown in the research [20] in Fig. 1.

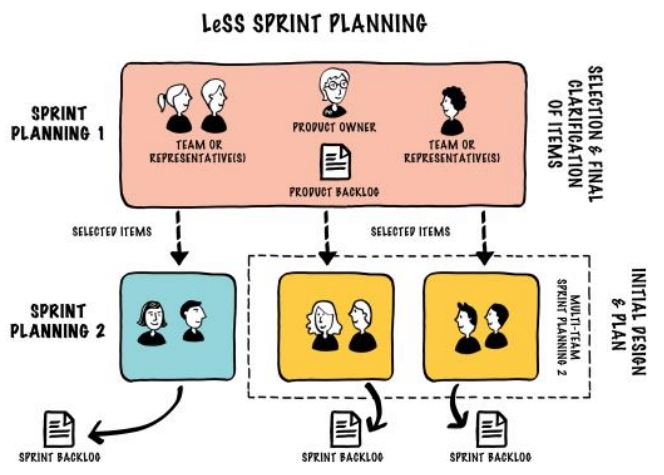

Fig. 1. Sprint Planning Meeting in Scrum

Daily Meeting: In this meeting, the team shares information on the progress of the Sprint and collaborates to make the necessary adaptations. For this purpose, the Sprint Backlog is carried out as shown in Fig 2. 


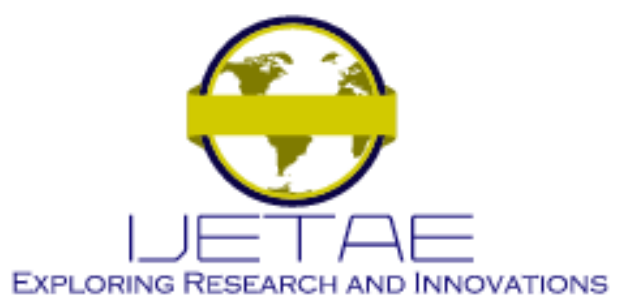

International Journal of Emerging Technology and Advanced Engineering

Website: www.ijetae.com (E-ISSN 2250-2459, Scopus Indexed, ISO 9001:2008 Certified Journal, Volume 11, Issue 12, December 2021)

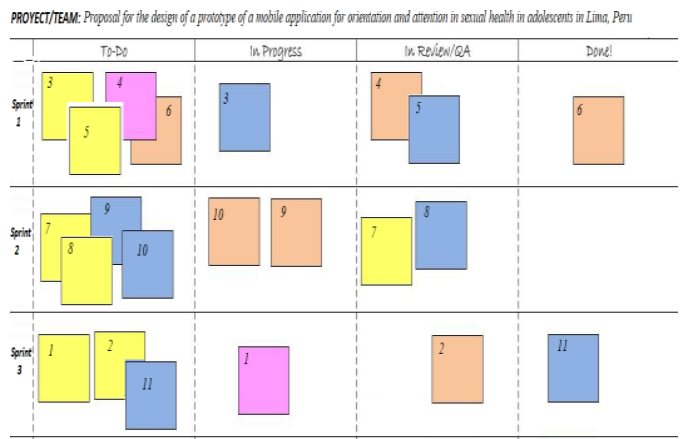

Fig. 2. Sprint Backlog

Sprint Review Meeting: In this meeting the team presents the deliverable product for each sprint. In addition to reporting the problems that were encountered during the execution process. This meeting aims to make decisions that will help to continue improving.

Sprint 1: This sprint will show the design of the prototype of the user stories 3, 4, 5 and 6. Fig. 3 will show the Main Menu that relates the story 3 and 4 of our backlog.

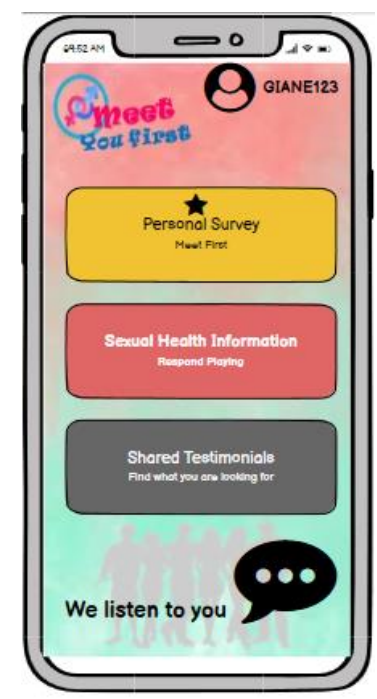

Fig. 3. Prototype Design Main Menu

This design shows the survey of initial questions to find out the degree of knowledge of adolescents regarding sexual health, this includes stories 5 and 6 as shown in Fig. 4.

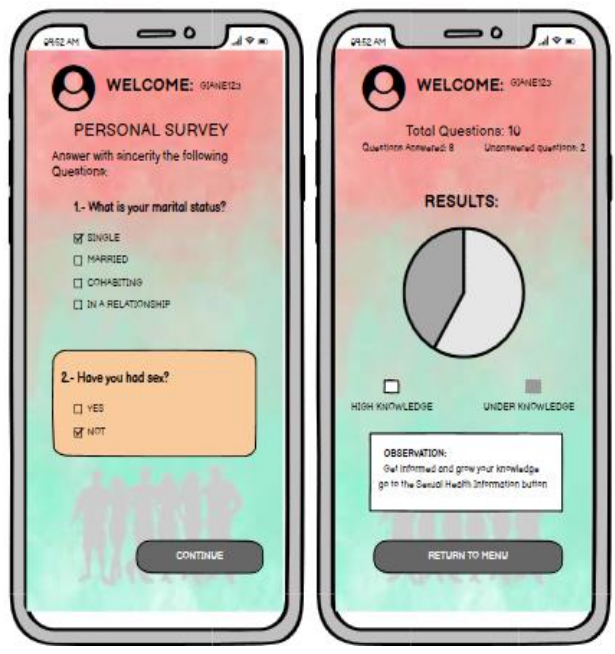

Fig. 4. Personal survey of the prototype application

Sprint 2: In this sprint the prototype of user stories 7, 8, 9 and 10 will be shown. Fig. 5 shows the interface through phases in an interactive way as mentioned in the deliverable of story 7 , so the teenager will be able to select the phase he or she would like to start giving knowledge about sexual health.

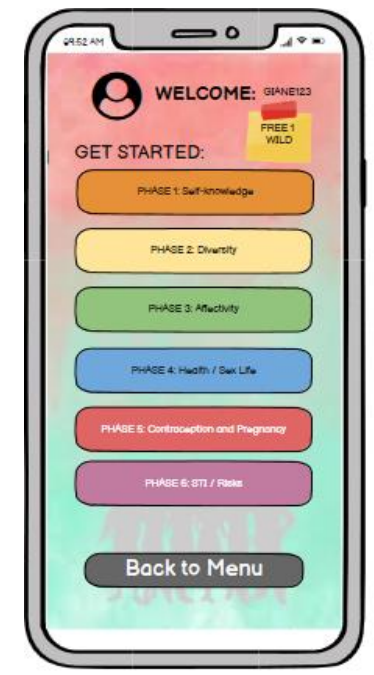

Fig. 5. Interface of sexual information by phases 


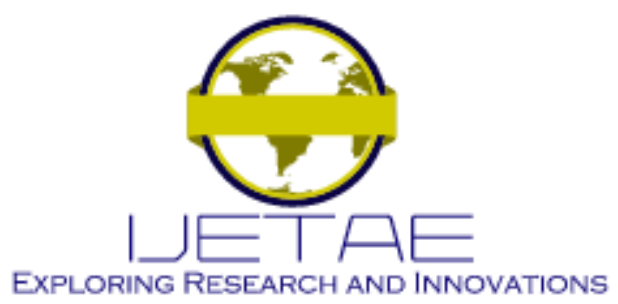

International Journal of Emerging Technology and Advanced Engineering

Website: www.ijetae.com (E-ISSN 2250-2459, Scopus Indexed, ISO 9001:2008 Certified Journal, Volume 11, Issue 12, December 2021)

In addition, when you enter the phase you will have a round of questions for your instruction. As shown in Fig. 6, you will have a help button in case you cannot find the answer and at the end you will be able to know your score and the jokers you won for the help of other phases. This makes the deliverable of user stories 8 and 9.

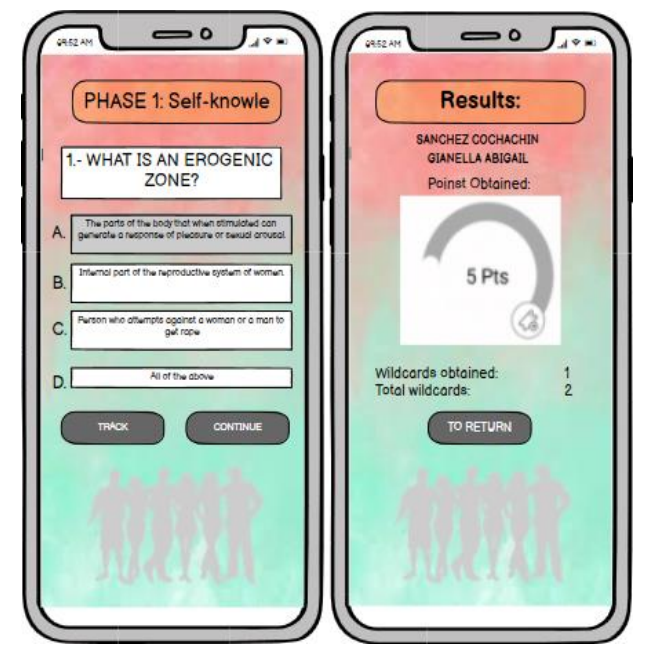

Fig. 6. Interface of questions per phase and results obtained

On the other hand, we have the prototype design of the user story 10 of our backlog, which shows a gallery of testimonials in videos for young people on issues of sexual health. Also, an interface to download the video and share it as shown in Fig. 7.

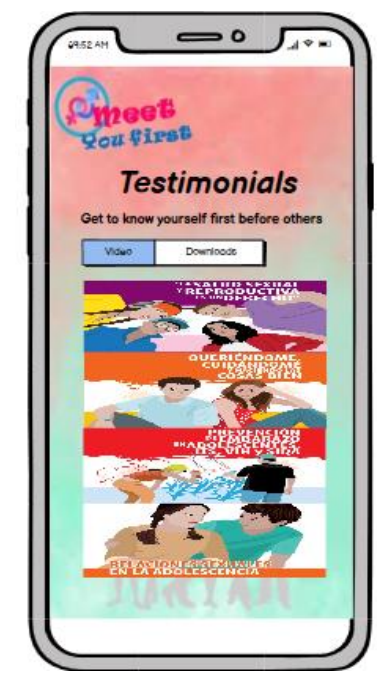

Fig. 7. Sexual Health Testimonials Interface
Sprint 3: This sprint will show the design of the prototype of story 1, 2 and 11 of our backlogs. Fig. 8 shows the Login interface of our application to access the main menu, and on the other hand it shows the user registration interface for logging in a dynamic and simple way.

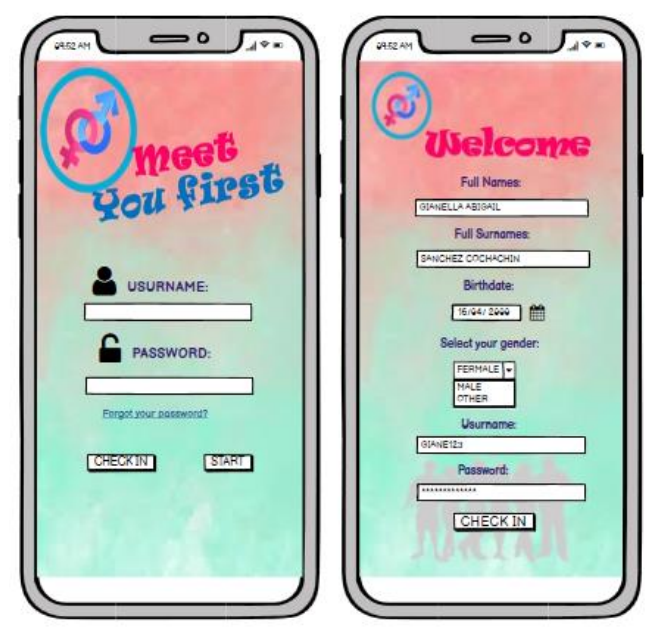

Fig. 8. Sexual Health Testimonials Interface

Therefore, an online chat will be implemented as shown in Fig. 9, so that when a question is asked, an immediate answer is given. Therefore, when using this Bot chat software, the user will be allowed to ask additional questions such as where can I get help for family planning, this software will send a link of information totally secure.

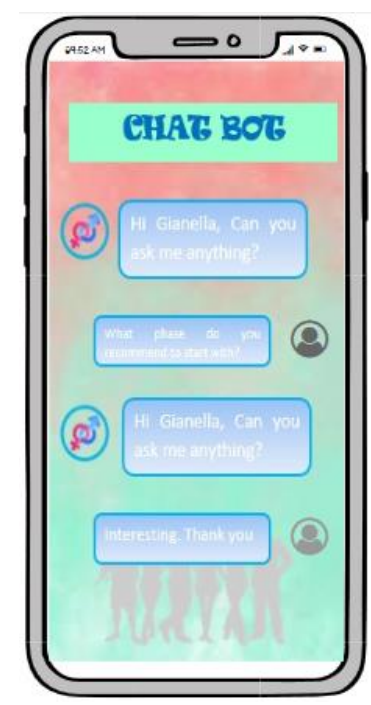

Fig 9: Chat Interface Bot 


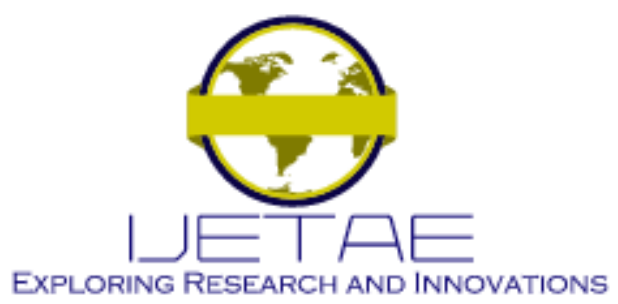

International Journal of Emerging Technology and Advanced Engineering

Website: www.ijetae.com (E-ISSN 2250-2459, Scopus Indexed, ISO 9001:2008 Certified Journal, Volume 11, Issue 12, December 2021)

Sprint Retrospective Meeting: the recently finished sprint, whose objective is to be able to achieve actions that everyone can do and the changes that could be made for the next sprint. And that's why the state of the previous sprint was announced, the problems it had, what was done well, what we want to improve and what measures we will take to make it possible. That's why we finished with the last sprint and delivered the product design in a short time.

\section{RESUlTs AND Discussions}

\section{A. About Implementation}

The design of the prototype of the mobile application for the orientation and attention in sexual health of the adolescents of North Lima, Peru, was completed. This is why, finalizing the requirements that were had in the constant meetings that were held for a future implementation of our proposal, which aims to provide knowledge to these young people of the future on sexuality in an interactive way through the design of the prototype. As we have in a previous study on mobile application modeling thanks to the Balsamiq Mockups software [21]. In order to verify this research, a survey was carried out using Google Forms and was directed only at adolescents in Lima and the north of the country. In addition, the most important thing is that they have an average level of knowledge about sexual health as shown in Fig. 10, using questions about sexual self-knowledge taken from the research [7].

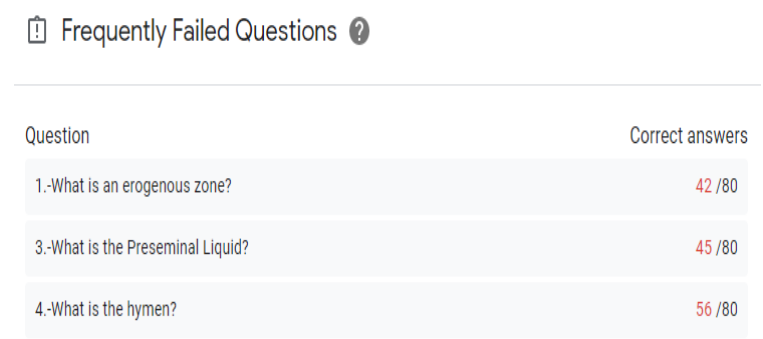

Figure 10: Survey questions in which the Lima teenager frequently fails.
In addition, a study carried out in the city of Trujillo also showed the lack of knowledge of adolescents on this subject, indicating their low and medium level of knowledge regarding their sexual and reproductive health as shown in the study [22] in Fig. 11.

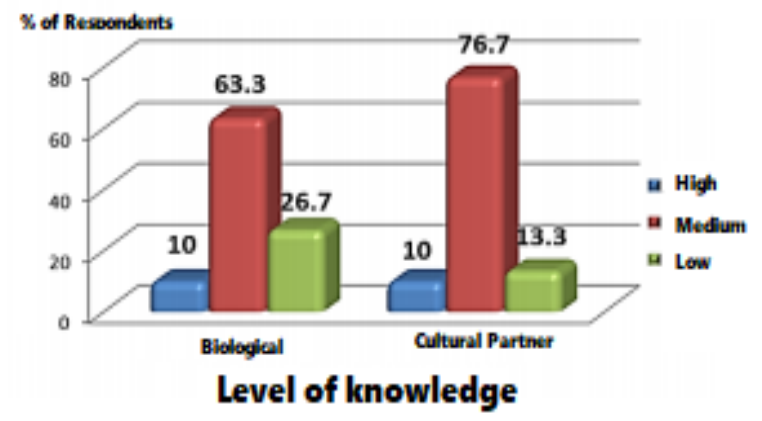

Fig 11: Level of knowledge about sexual health and Reproduction in adolescents in Trujillo

Finally, there is an investigation of the needs of Peruvian adolescents at the secondary level where they threw three blocks for good learning in sexual and reproductive health as shown in the research [23] in Fig 12.

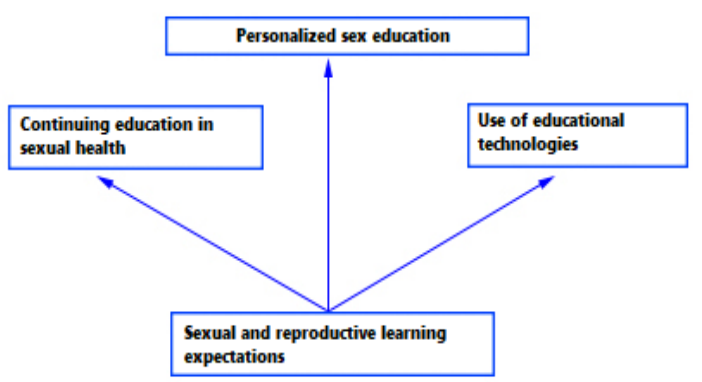

Fig 12: Educational needs of adolescents in sexual and reproductive health.

That is why in proposing this application for orientation and care in sexual health we intend to improve the knowledge and needs they require for these issues, showing them that they are not alone but giving them all the help they need with the help of technology and thanks to the survey we had a good reception from them wanting to use this mobile application as shown in Fig. 13. 


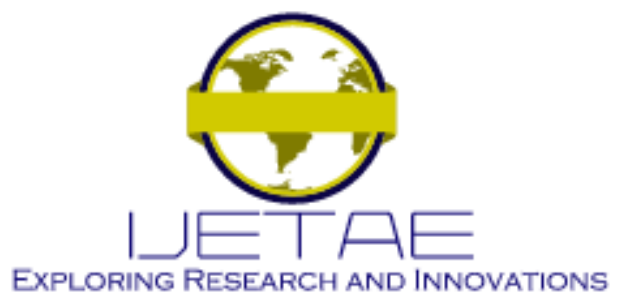

International Journal of Emerging Technology and Advanced Engineering

Website: www.ijetae.com (E-ISSN 2250-2459, Scopus Indexed, ISO 9001:2008 Certified Journal, Volume 11, Issue 12, December 2021)

6.- What do you think if a mobile application is designed to provide you with knowledge and orientation of sexual health in an interactive way through question games in phases, online chat for additional questions, videos on interesting topics of sexuality, lived cases. 80 responses

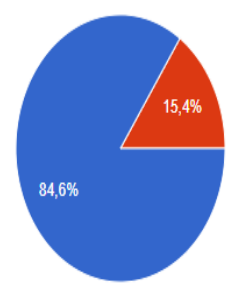

Me parece genial, puesto que me ayudara a poder conocerme mas - No me parece, No me gusta hablar de esos temas

Fig 13: Percentage of teenagers surveyed who think the application design is great

\section{B. About the Methodology}

Advantages: One of the advantages of Scrum is that the development team has a constant daily communication through meetings for about 15 minutes to complete the difficulties and progress of the Sprint this helps a constant review on the best for the final product of our mobile application.

Disadvantages: One disadvantage to be considered is the final product, since how it changes if more user stories are added will not be controllable.

Differences: In the differences we can find that in the Scrum methodology projects are delivered in a short time because if we used the PMI methodology would have focused only on project management using PMBOK for basic processes through phases to manage good practices.

\section{CONCLUSIONS}

In conclusion, the proposal for the mobile application prototype design has been successfully completed. Showing all the requirements that were had in the course of the investigation. In this way, the proposal will help adolescents to orient themselves and get to know each other regarding their sexual health, with the interactive tools that the application has, such as question games, videos on important sexuality topics and a chat to freely ask about the doubts they have. All of this was designed thanks to Balsamiq since it was beneficial to be able to observe how the interface of the application will look like.

In addition, the Scrum Methodology that we use helps in the order and good communication between work teams to be able to accelerate and obtain in a short time a proposal through its great phases.
This is the basis for future research that can add more requirements to this product backlog, for example, why not add a map with places to talk to young people about sexuality provided by the Peruvian state.

\section{REFERENCES}

[1] M. d. 1. A. Mena Serrano, "Diseño de aplicación para dispositivo móvil basada en la sinestesia para informar sobre salud sexual a nivel preventivo primario a jóvenes de 17 a 19 años de la puce quito que asisten a la coordinación de promoción de salud de bienestar estudiantil,"' ' B.S. thesis, PUCE, 2018.

[2] M. L. Ildefonso Soto, "Intervención educativa sobre salud sexual y reproductiva y su efecto en el conocimiento de los adolescentes del quinto año de secundaria de la institución educativa privada "trilce", noviembre-diciembre 2015," 2016.

[3] J. Nycander-Toth, "Campana de prevención:" infórmate sin paltas"," 2018.

[4] F. González González, S. L. Calero Castañeda, et al., "Comparación de las metodologías cascada y ágil para el aumento de la productividad en el desarrollo de software," $\mathrm{PhD}$ thesis, Universidad Santiago de Cali, 2019.

[5] C. R. Vargas, "Metodología de desarrollo ágil en programación extrema," MoleQla: revista de Ciencias de la Universidad Pablo de Olavide, no. 18, pp. 3-3, 2015

[6] O. Marquez and M. Jeniser, "Análisis de las metodologías agiles de desarrollo software," B.S. thesis, Babahoyo, UTB 2019, 2019.

[7] M. de Santiago, "100 preguntas sobre sexualidad adolescente," Municipalidad de Santiago, Santiago de Chile, 2016.

[8] T. Dimes, Conceptos Básicos de Scrum: Desarrollo de software Agile y manejo de proyectos Agile. Babelcube Inc., 2015.

[9] C. Rodriguez and R. Dorado, ¿por qué implementar scrum?, Revista Ontare, vol. 3, no. 1, pp. 125-144,2015.

[10] L. M. A. López, M. E. R. Rivera, and N. L. S. Palomino, "Análisis de aplicaciones empleando la computación en la nube de tipo paas y la metodología ágil scrum," Industrial data, vol. 18, no. 1, pp. 149160,2015

[11] S. I. Mariño and P. L. Alfonzo, "Implementación de scrum en el diseño del proyecto del trabajo final de aplicación", Scientia et technica, vol. 19, no. 4, pp. 413-418, 2014.

[12] S. Ashraf and S. Aftab, "IScrum: An improved scrum process model," International Journal of Modern Edu-cation and Computer Science, vol. 9, no. 8, p. 16, 2017.

[13] J. C. A. Becerra and C. E. D. Vanegas, "Propuesta de un método para desarrollar sistemas de información geográfica a partir de la metodología de desarrollo ágil-scrum.," Cuaderno Activa, vol. 10, pp. 29-41, 2018

[14] S. Faranello, Balsamiq wireframes quick start guide. Packt Publishing Ltd, 2012

[15] J. J. Alarco and E. V. Álvarez-Andrade, "Google docs: Una alternativa de encuestas online," Educación Médica, vol. 15, no. 1, pp. 9-10, 2012.

[16] C. Wang, W. Duan, J. Ma, and C. Wang, "The research of android system architecture and application program-ming," in Proceedings of 2011 International Conference on Computer Science and Network Technology, IEEE, vol. 2, 2011, pp. 785-790. 


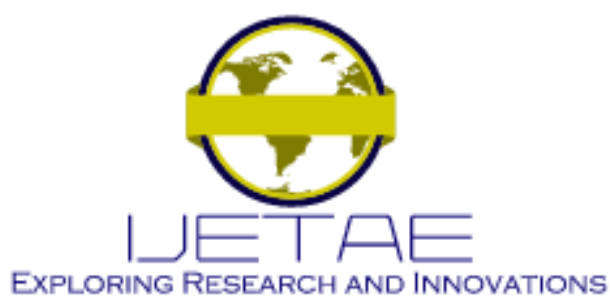

International Journal of Emerging Technology and Advanced Engineering

Website: www.ijetae.com (E-ISSN 2250-2459, Scopus Indexed, ISO 9001:2008 Certified Journal, Volume 11, Issue 12, December 2021)

[17] J. C. O. Cabello, Diseño de páginas Web con XHTML, JavaScript y CSS. Grupo Editorial RA-MA, 2008

[18] R. Grycuk, A. Wojciechowski, W. Wei, and A. Siwocha, "Detecting visual objects by edge crawling," Journal of Artificial Intelligence and Soft Computing Research, vol. 10, no. 3, pp. 223-237, 2020

[19] B. A. Shawar and E. Atwell, "Chatbots: Are they really useful?" In Ldv forum, vol. 22, 2007, pp. 29-49.

[20] "Sprint Planning One - Large Scale Scrum (LeSS)", Large Scale Scrum (LeSS), $2020 . \quad$ [Online]. Available: https://less.works/less/framework/sprint-planning-one. [Accessed: 11- Oct- 2020].
[21] P. Rupay and E. Héctor, "Prototipo de una aplicación móvil para el monitoreo a pacientes con males cardiacos en el distrito de lima metropolitana, 2016-2021," 2016

[22] E. Benites and J. Chunga, "Efectividad de un programa educativo en adolescentes sobre el nivel de conocimiento en salud sexual y reproductiva," SCIÉNDO, vol. 20, no. 2, pp. 61-69, 2017.

[23] E. Vela Arevalo, "Necesidades educativas en salud sexual y reproductiva en adolescentes peruanos de nivel secundario," Revista Cubana de Salud Pública, vol. 42,no. 3, pp. 396-406, 2016 